\title{
Public Health, Intellectual Property, and the Trade and Investment Law Challenges to Australia and Uruguay's Tobacco Packaging Laws
}

\author{
Suzanne Zhou $^{*}$.. and Jonathan Liberman ${ }^{* *}{ }^{*}$
}

\begin{abstract}
The trade and investment disputes brought against Australia's tobacco plain packaging laws and Uruguay's large graphic health warnings and restrictions on tobacco brand variants are key cases on the relationship between public health and intellectual property. Both cases have been decided in favour of the respondent states, and they are important victories not only for tobacco control but for public health flexibilities in intellectual property agreements more broadly. Key points to take from the jurisprudence include: its confirmation that trademarks do not give trademark owners the right to use those trademarks to market harmful products, its clarification of the scope of intellectual property protections under international investment law, and its findings on the status of the Doha Declaration on the TRIPS Agreement and Public Health and on interpreting the WTO Agreement on Trade-Related Aspects of Intellectual Property Rights coherently with public health more generally.
\end{abstract}

Keywords: intellectual property, public health, World Trade Organization, international investment law, Australia - Tobacco Plain Packaging, Philip Morris v Uruguay

\section{Introduction}

Tobacco industry internal documents now in the public domain show that in the 1990s, when researchers first proposed that tobacco products be sold in 'plain packaging' with large graphic health warnings as a way to reduce the promotional effects of tobacco packaging, the tobacco industry responded with a strategy to recast public debate on the measures in terms of trade and intellectual property rights instead of in terms of health. Despite receiving legal advice that these arguments did not have merit, the tobacco industry claimed, over decades and across jurisdictions, that plain packaging and graphic health warnings would expropriate their trademarks, violate international intellectual property agreements, and create barriers to trade. ${ }^{1}$

These arguments later became aggressive, multi-level litigation. In Australia, the first country to adopt tobacco plain packaging, tobacco companies launched or supported litigation against plain packaging in the High Court of Australia, the World Trade Organization ('WTO'), and an investment tribunal under the 1993 Hong Kong Australia bilateral investment treaty... In Uruguay, Philip Morris companies launched an investor-state challenge to graphic health warnings requirements and restrictions on tobacco brand variants.. ${ }^{3}$. Similar cases have been brought in domestic courts around the world.. ${ }^{4}$ Notwithstanding the differences in the substantive law governing

\footnotetext{
${ }^{*}$ Legal Policy Advisor, McCabe Centre for Law and Cancer; LLM (Cantab); LLB (Hons), BMus (Hons) (Melb). Email: <suzanne.zhou@mccabecentre.org>.

** Director, McCabe Centre for Law and Cancer; Associate Professor, Melbourne Law School and Melbourne School of Population and Global Health; MPub\&IntLaw (Melb); LLB (Hons), BA (Monash).

${ }^{1}$ Eric Crosbie, Robert Eckford and Stella Bialous, ‘Containing Diffusion: The Tobacco Industry’s Multipronged Trade Strategy to Block Tobacco Standardised Packaging’ (2019) 28(2) Tobacco Control 195.

2 JT International SA v Commonwealth (2012) 250 CLR 1; Philip Morris Asia Ltd v The Commonwealth of Australia (Award on Jurisdiction and Admissibility) (Permanent Court of Arbitration, Case No 2012-12, 17 December 2015); Panel Report, Australia-Certain Measures Concerning Trademarks, Geographical Indications and Other Plain Packaging Requirements Applicable to Tobacco Products and Packaging, WT/DS435/R, WT/DS441/R, WT/DS458/R, WT/DS467/R (28 June 2018) ('Australia-Plain Packaging').

${ }^{3}$ Philip Morris Brands Sàrl, Philip Morris Products S.A., and Abal Hermanos S.A. v Oriental Republic of Uruguay (Award) (ICSID Arbitral Tribunal, Case No ARB/10/7, 8 July 2016) ('Philip Morris v Uruguay').

${ }^{4}$ See generally Suzanne Y Zhou, Jonathan D Liberman and Evita Ricafort, 'The Impact of the WHO Framework Convention on Tobacco Control in Defending Legal Challenges to Tobacco Control Measures’ (2019) 28(Suppl 2) Tobacco Control s113.
} 
the relevant legal regimes, these legal challenges have drawn on a shared body of arguments, under a common strategy of invoking intellectual property rights to prevent the adoption of plain packaging and graphic health warnings laws worldwide. ${ }^{5}$. The strategy has proven unsuccessful: Australia and Uruguay comprehensively won their disputes (although an appeal is still pending in Australia's WTO case), and the tobacco industry has consistently lost domestic legal cases against plain packaging and graphic health warnings around the world.

The tobacco control cases have important systemic implications for the relationship between international intellectual property law and public health. International intellectual property agreements, which require states parties to adopt certain minimum standards of intellectual property protection into their domestic law, have significant and often controversial implications for health. ${ }^{6}$. The best known of these is their implications for the availability, accessibility and affordability of medicines and other health technologies, but intellectual property is also relevant to marketing and consumer information relating to unhealthy or dangerous products, new biotechnologies, ownership and control of health data, food and agricultural systems, environmental health, and health and medical research, among others. ${ }^{7}$. The tobacco control cases are some of the most detailed elaborations of this relationship, and are thus relevant to many of these other areas as well.

Three aspects of the tobacco control cases in particular have broader significance for public health: their findings on the nature of intellectual property protections under international law, their findings on the relationship between intellectual property and international investment law, and their findings on how public health informs the interpretation and application of WTO's Agreement on Trade-Related Aspects of Intellectual Property Rights ('TRIPS')... 8

\section{Background}

Plain (or standardised) packaging is a regulatory measure that requires tobacco packaging to be sold in packs of a standard shape, colour, and fonts, and prohibits the use of other colours, imagery, promotional text, textures, finishes, fonts, pack shapes and scents on tobacco packaging, except for consumer or regulatory information that is explicitly permitted and a plain brand name and variant to distinguish the products. It is generally implemented together with a requirement that large graphic (or pictorial) health warnings be placed on tobacco packaging. 9 .

Plain packaging does not affect the registration of trademarks, nor does it prevent companies from suing each other for infringement, or from using their trademarks in internal communications. However, it does restrict the ability to use figurative trademarks on the pack to market to consumers and regulates how word trademarks may appear on tobacco packaging. The rationale for restricting such use is to reduce ability of pack to act as a 'minibillboard' to the consumer, to make the graphic health warning more noticeable, and to reduce certain misleading practices such as the use of light colours to promote the false impression that certain tobacco products are less harmful than others. ${ }^{10}$. Plain packaging and large graphic health warnings implement obligations under the WHO Framework Convention on Tobacco Control, ${ }^{11}$. as elaborated by implementation guidelines adopted by its Conference of the Parties.. ${ }^{12}$. The measures have also been endorsed as 'best buys' for combating noncommunicable (or chronic) diseases by the World Health Assembly, the governing body of the World Health

\footnotetext{
${ }^{5}$ Crosbie, Eckford and Bialous (n 1).

${ }^{6}$ See generally Frederick M Abbott, 'Health and Intellectual Property Rights' in Gian Luca Burci and Brigit Toebes (eds), Research Handbook on Global Health Law (Edward Elgar Publishing, 2018) 135.

${ }^{7}$ See generally Alberto Alemanno and Enrico Bonadio (eds), The New Intellectual Property of Health: Beyond Plain Packaging (Edward Elgar Publishing, 2016); Abbott (n 6).

${ }^{8}$ Marrakesh Agreement Establishing the World Trade Organization, opened for signature 15 April 1994, 1867 UNTS 3 (entered into force 1 January 1995) annex 1C ('Agreement on Trade-Related Aspects of Intellectual Property Rights').

${ }^{9}$ See World Health Organization, Tobacco Plain Packaging: Global Status Update (World Health Organization, 2018).

${ }^{10}$ See, eg, Tobacco Plain Packaging Act 2011 (Cth) s 3.

${ }^{11}$ Opened for signature 16 June 2003, 2302 UNTS 166 (entered into force 27 February 2005) ('WHO FCTC’).

${ }^{12}$ Conference of the Parties to the WHO Framework Convention on Tobacco Control, Guidelines for implementation of Article 11 of the WHO Framework Convention on Tobaco Control (Packaging and Labelling of Tobacco Products), COP Decision FCTC/COP3(10), $3^{\text {rd }}$ sess, $4^{\text {th }}$ plen $\mathrm{mtg}$, FCTC/COP/3/DIV/3 (22 November 2008) para 46; Conference of the Parties to the WHO Framework Convention on Tobacco Control, Guidelines for implementation of Article 13 of the WHO Framework Convention on Tobaco Control (Tobacco Advertising, Promotion and Sponsorship), COP Decision FCTC/COP3(12), 3rd sess, $4^{\text {th }}$ plen mtg, FCTC/COP/3/DIV/3 (22 November 2008) para 16.
} 
Organization ('WHO'). ${ }^{13}$. Both measures are now common; more than 100 countries have adopted graphic health warnings covering $50 \%$ or more of the pack, and sixteen countries at the time of writing had adopted plain packaging.. ${ }^{14}$

The tobacco industry has vehemently opposed such measures (as well as other tobacco control laws and regulations). It has frequently argued either that plain packaging/large graphic health warnings are inconsistent with obligations under TRIPS, or that they expropriate intellectual property as an asset protected by investment law. Intellectual property arguments are not the only aspect of tobacco control legal challenges-in the Australia WTO case, the claimants also argued that the measure was more trade restrictive than necessary; in both the Uruguay and Australia investment cases, Philip Morris companies argued that the measure was arbitrary; and domestically, the cases also often invoke rights relating to commercial speech and freedom of enterprise. However, intellectual property arguments are one of the most common arguments in such litigation.. ${ }^{15}$

\section{The Nature of Intellectual Property Rights}

Intellectual property arguments in tobacco control cases generally consist of either claims that ownership of a trademark and/or related rights prevents restrictions on the use of that trademark (the 'right to use' argument), or claims that restricting use of a trademark and/or related rights impedes the enjoyment of other rights such as registration or prevention of infringement (implicit 'right to use' arguments).

\section{(a) The 'Right to Use' Argument}

A key basis for these arguments is that there is a positive right to use a trademark, and that regulation of use of trademarks infringes that right. The so-called right to use a trademark is allegedly implied by TRIPS article 15, which concerns trademark registration, TRIPS article 16.1, which provides for a right to prevent others from infringing on a trademark, and various provisions of the Paris Convention on the Protection of Industrial Property that concern registration and infringement. ${ }^{16}$. Variations on this argument are also made under domestic and regional intellectual property instruments, and in relation to other forms of intellectual property, such as geographical indications and designs.

The central flaw in the argument is that it is well established that intellectual property rights under international law are rights to register intellectual property and negative rights to exclude third parties, and not positive rights to use them. This is apparent from the wording of the provisions, but was also established in jurisprudence and practice prior to plain packaging. In European Communities-Geographical Indications, for example, the panel noted that

[t]hese principles reflect the fact that the TRIPS Agreement does not generally provide for the grant of positive rights to exploit or use certain subject matter, but rather provides for the grant of negative rights to prevent certain acts. This fundamental feature of intellectual property protection inherently grants Members freedom to pursue legitimate public policy objectives since many measures to attain those public policy objectives lie outside the scope of intellectual property rights and do not require an exception under the TRIPS Agreement. ${ }^{17}$

\footnotetext{
${ }^{13}$ World Health Organization, Best Buys and Other Recommended Interventions for the Prevention and Control of Noncommunicable Diseases: Updated (2017) Appendix 3 of the Global Action Plan for the Prevention and Control of Noncommunicable Diseases 2013-2020 (31 May 2017), adopted by World Health Assembly, Preparation for the Third High-level Meeting of the General Assembly on the Prevention and Control of Non-communicable Diseases, to Be Held in 2018, WHA Res 70.11, B comm, $10^{\text {th }}$ plen mtg, WHO Doc WHA70/2017/REC/1 (31 May 2017).

${ }^{14}$ Canadian Cancer Society, Cigarette Package Health Warnings: International Status Report (Canadian Cancer Society, $6^{\text {th }}$ ed, 2018); Michelle M Scollo and Elizabeth M Greenhalgh, 'International Flow-On Effects' in Michelle M Scollo and Margaret H Winstanley (eds), Tobacco in Australia: Facts and Issues (Cancer Council Victoria, 2019)

$<$ https://www.tobaccoinaustralia.org.au/chapter-11-advertising/indepth-11a-packaging-as-promotion/11a-6-internationalflow-on-effects>.

${ }^{15}$ See Zhou, Liberman and Ricafort (n 4).

${ }^{16}$ Opened for signature 14 July 1967, 828 UNTS 305 (entered into force 26 April 1970).

${ }^{17}$ Panel Report, European Communities-Protection of Trademarks and Geographical Indications for Agricultural Products and Foodstuffs, WTO Doc WT/DS174/R (15 March 2005) [7.210]; Panel Report, European Communities—Protection of Trademarks and Geographical Indications for Agricultural Products and Foodstuffs, WTO Doc WT/DS290/R (15 March
} 
A similar view of trademark rights as negative rights had been expressed by the World Intellectual Property Organization in the 1990s, both in response to tobacco industry enquiries, ${ }^{18}$ and as an opinion provided to WHO for the initial feasibility study for the WHO FCTC in 1995, which examined how the proposed convention would interact with trade and intellectual property agreements. ${ }^{19}$.

The 'right to use' argument has nevertheless been a key basis for tobacco industry legal challenges. It has now been conclusively rejected in at least eight cases, which make clear that trademark rights are negative rights opposable against third parties, and not positive rights to use a trademark that are opposable against state regulation. ${ }^{20}$. As the Philip Morris v Uruguay tribunal explained:

the trademark holder does not enjoy an absolute right of use, free of regulation, but only an exclusive right to exclude third parties from the market so that only the trademark holder has the possibility to use the trademark in commerce, subject to the State's regulatory power.. ${ }^{21}$

\section{(b) Implicit 'Right to Use' Arguments}

The Australia-Plain Packaging WTO decision is the latest decision to confirm that trademarks under TRIPS are negative rights. It is, however, not primarily about that argument, as most of the complainants ultimately conceded that there was no right to use a trademark. ${ }^{22}$. Instead, most of the complainants argued that tobacco companies not being able to use trademarks would mean that the trademarks could not become distinctive enough to be registered or remain distinctive enough to be the subject of infringement or unfair competition claims - in other words, while conceding there was no general right to use, they argued that there was a right to use a trademark for specific purposes linked to other rights in TRIPS. These arguments were also rejected by the panel.

The WTO panel found that TRIPS protections for registration and against infringement referred only to the obligation to register trademarks that were distinctive at the time of registration and to provide legal rights to prevent infringement and unfair competition by third parties. ${ }^{23}$ TRIPS did not implicitly oblige WTO members to guarantee general market conditions relating to trademarks, nor did it require them to ensure that consumers would recognise the trademarks in perpetuity. ${ }^{24}$. Fundamentally, the panel recognised that these arguments were not materially different from the right to use argument itself. The decision of the panel confirms that TRIPS does not prevent WTO members from regulating the marketing of harmful products, including by prohibiting the use of trademarks - TRIPS contains obligations to implement legal rights relating to registration and infringement, and not obligations to guarantee market conditions for intellectual property holders.

\section{Intellectual Property as an Investment}

\footnotetext{
2005) [7.246]. See also Appellate Body Report, United States-Section 211 Omnibus Appropriations Act of 1998, WTO Doc WT/DS176/AB/R (2 January 2002) [186].

${ }^{18}$ Letter from Ludwig Baeumer, World Intellectual Property Organization, to David A Latham, 6 July 1994

$<$ https://www.industrydocuments.ucsf.edu/tobacco/docs/\#id=gjxn0198>.

${ }^{19}$ World Health Organization, The Feasibility of Developing an International Instrument for Tobacco Control: Report by the Director-General, Executive Board, 97th session, Provisional Agenda Item 6, EB97/INF.DOC./4 (30 November 1995) para 21.

${ }^{20}$ See, eg, JT International SA v Commonwealth (n 2); Loi de modernisation de notre système de santé, Conseil constitutionnel [French Constitutional Court], decision n ${ }^{\circ}$ 2015-727 DC, 21 January 2016 reported in JO, 27 January 2016; $R$ (British American Tobacco UK Ltd) v Secretary of State for Health [2016] EWHC 1169 (Admin); Philip Morris $v$ Uruguay (n 3); R (British American Tobacco UK Ltd) v Secretary of State for Health [2017] 2 All ER 691; Société JT International SA, Conseil d'État [French Administrative Court], decision n 399117, 399789, 399790, 399824, 399883, 399938, 399997, 402883, 403472, 403823, 404174,

404381, 404394, 23 December 2016; Australia_Plain Packaging, WT/DS435/R, (n 2); British American Tobacco Ltd v Attorney General, Constitutional Court of Uganda, Case No 46 of 2016, 28 May 2019.

${ }^{21}$ Philip Morris v Uruguay (n 3) [271].

${ }^{22}$ Australia-Plain Packaging (n 2) [7.1978].

${ }^{23}$ See, eg, ibid [7.1774], [7.1873]-[7.1874], [7.1894]-[7.1897], [7.1912], [7.1999]-[7.2002], [7.2016], [7.2031], [7.2040],

[7.2050], [7.2129], [7.2794], [7.2869]-[7.2870].

${ }^{24}$ Ibid [7.1999]-[7.2002], [7.2010]-[7.2016].
} 
Tobacco companies have also argued that restrictions on the use of trademarks violate international investment law, particularly obligations relating to expropriation of property. Three points can be drawn from the case law on these arguments-first, it is not necessarily the case that an individual trademark will be the relevant investment; second, the relevant property rights are not absolute and the interests of trademark owners must be balanced with broader public interests; and finally, intellectual property rights are not to be treated as specific commitments to investors but as part of the general regulatory framework of a state.

In Philip Morris $v$ Uruguay, the tribunal found that Uruguay's packaging and labelling measures did not expropriate Philip Morris' trademarks. ${ }^{25}$. Philip Morris had argued that Uruguay's requirement for graphic health warnings covering $80 \%$ of the front and back of tobacco packs, as well as a measure called the 'single presentation requirement' which required each brand family of tobacco products to be marketed in only one variant, expropriated its intellectual property.. ${ }^{26}$. The tribunal rejected both claims, on the basis that there was no substantial deprivation of an investment. There was 'not even a prima facie case' in relation to the graphic health warnings, given that the trademarks remained visible on the pack. ${ }^{27}$. The claim relating to the brand variant restrictions was also rejected, because the relevant investment for a general regulatory measure of that nature was the Uruguayan business as a whole, not each individual trademark.. ${ }^{28}$. Given the value remaining in the Uruguayan business, the regulatory measures had not substantially deprived Philip Morris of their investment-it was not the role of investment law to compensate a 'partial loss of the profits that the investment would have yielded absent the measure'. ${ }^{29}$. The tribunal went on to find that even if the measures had substantially deprived Philip Morris of its investment, they would not have been an expropriation given that the measures were clearly a non-discriminatory, good faith regulation to protect public health and therefore an exercise of Uruguay's sovereign right to regulate. ${ }^{30}$.

The Philip Morris v Uruguay tribunal made several other findings on the relationship between international intellectual property law and international investment law. In the context of fair and equitable treatment, after the majority ruled that neither of Uruguay's measures could be characterised as arbitrary, the Tribunal unanimously found that ownership of a trademark does not create any legitimate expectation that one will be able to use it, and that changes in laws that might affect the value of a trademark are not breaches of legitimate expectations or legal stability. ${ }^{31}$. It also found that ownership of a trademark does not create commitments to investors that are enforceable under an umbrella clause, and that the existence of a trademark is part of a general regulatory framework and not a specific promise to an investor that that framework will not be changed. ${ }^{32}$. The tribunal's decision further confirms that trademarks are private law rights against third parties and not rights against the state- they do not create obligations for host states to freeze their regulatory frameworks regarding public health.

\section{Weighing Economic and Societal Interests in the Interpretation and Application of the TRIPS Agreement}

More broadly, the tobacco cases discuss extensively how to weigh the different interests at stake in intellectual property cases, and the place of public health within the TRIPS Agreement. These are of particular significance in the WTO panel's findings on article 20 of TRIPS. Article 20 provides that 'the use of trademarks in the course of trade shall not be unjustifiably encumbered by special requirements', and is the only provision of TRIPS that regulates restrictions on use of trademarks. ${ }^{33}$

The panel decided that plain packaging was not an 'unjustifiable' encumbrance, because the public health rationale of plain packaging provided 'sufficient support' for restricting or prohibiting the relevant trademarks on tobacco packaging. ${ }^{34}$. It noted that the trademark restrictions imposed by plain packaging undisputedly 'address an exceptionally grave domestic and global health problem involving a high level of preventable morbidity and

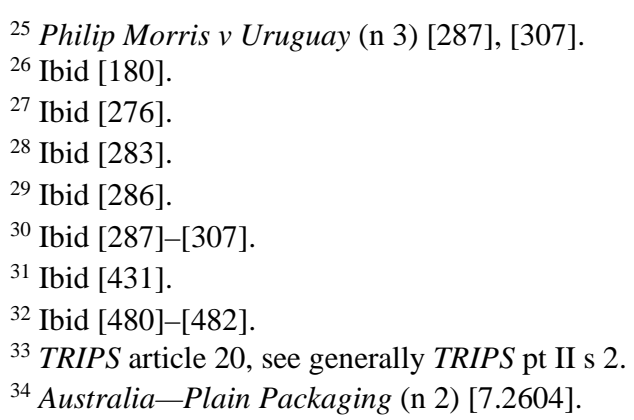


mortality', ${ }^{35}$. and that they 'are capable of contributing, and do in fact contribute, to Australia's objective of improving public health by reducing the use of, and exposure to, tobacco products'. ${ }^{36}$. The panel found that standardising the appearance of packaging and restricting figurative features and signs, including trademarked ones, was 'integral' to the success of the measure, given the role of those exact features in encouraging tobacco product consumption, misleading consumers, and reducing the effectiveness of graphic health warnings. ${ }^{37}$. It considered that no other alternative would equally address these problems. ${ }^{38}$. It noted that Australia's measures were 'in line with the emerging multilateral public health policies in the area of tobacco control as reflected in the FCTC and the work under its auspices, including the Article 11 and Article 13 FCTC Guidelines'. ${ }^{39}$. It concluded that there was sufficient justification for encumbering the relevant trademarks.

In making these findings, the WTO panel clarified the status of the Doha Declaration on the TRIPS Agreement and Public Health, a Ministerial Declaration adopted in 2001 to address the impact of intellectual property on access to medicines. The Doha Declaration affirms that the TRIPS Agreement 'can and should be interpreted and implemented in a manner supportive of WTO members' right to protect public health'.. ${ }^{40}$. The panel found that paragraph 5 of the Doha Declaration, which recognises particular 'flexibilities' under the TRIPS Agreement, was a 'subsequent agreement' to the TRIPS Agreement under article 31(3)(a) of the Vienna Convention on the Law of Treaties (VCLT). ${ }^{41}$. The panel adopted the Doha Declaration's interpretation that the object and purpose of TRIPS was to be derived from articles 7 and 8 of TRIPS (titled 'objectives' and 'principles'), which recognise respectively that the objectives of the TRIPS Agreement include social and economic welfare, and that members may adopt measures necessary to protect public health and nutrition provided they are consistent with the remainder of the Agreement. ${ }^{42}$. The Doha Declaration and articles 7 and 8 therefore needed to be considered in interpreting TRIPS, in accordance with article 31 of the VCLT.

The panel's decision makes clear the role that marketing (including marketing that makes use of trademarks and other forms of branding) plays in driving tobacco consumption, and establishes that TRIPS, properly interpreted, does not prevent regulation of such marketing. Some uncertainty remains about the scope of the TRIPS article 20 as elaborated by the panel. In particular, the panel's interpretation of the other elements of article 20 is broad, and could potentially subject more measures to review by WTO panels on their policy merits than WTO members might originally have envisaged. ${ }^{43}$. It also remains unclear what standard of review 'sufficient support' requires, the panel having placed it somewhere between the weighing and balancing test required to prove that a measure is 'necessary' and the rational connection test used by WTO panels to examine whether a measure is 'arbitrary and unjustifiable'.. ${ }^{44}$ But overall, the WTO panel's decision establishes that the TRIPS Agreement's interpretation should be consonant with public health objectives, and emphasises the importance of balancing intellectual property protections with other social objectives.

The panel's decision also more broadly affirms the public health flexibilities under TRIPS. The panel's decision is the first since the Doha Declaration was adopted to grapple with its status and meaning, and it is also one of the few panel decisions to apply and discuss the role of articles 7 and 8 in interpreting TRIPS in detail.. ${ }^{45}$. The panel's conclusion that the Doha Declaration is a subsequent agreement to the TRIPS Agreement and its findings on

\footnotetext{
${ }^{35}$ Ibid [7.2592].

${ }^{36}$ Ibid [7.2604].

${ }^{37}$ Ibid [7.2593]-[7.2594].

${ }^{38}$ Ibid [7.2601]-[7.2603].

${ }^{39}$ Ibid [7.2604].

${ }^{40}$ Declaration on the TRIPS Agreement and Public Health, WTO Doc WT/MIN(01)/DEC/2 (14 November 2001) ('Doha Declaration'), para 4.

${ }^{41}$ Vienna Convention on the Law of Treaties, opened for signature 23 May 1969, 1155 UNTS 331 (entered into force 27 January 1980). See Australia_Plain Packaging (n 2) [7.2408]-[7.2409].

${ }^{42}$ Australia-Plain Packaging (n 2) [7.2399]-[7.2411].

${ }^{43}$ See, eg, Mark Davison and Patrick Emerton, 'Rights, Privileges, Legitimate Interests, and Justifiabilty: Article 20 of TRIPS and Plain Packaging of Tobacco’ (2014) 29 American University International Law Review 505.

${ }^{44}$ See Tania Voon, ‘Third Strike: The WTO Panel Reports Upholding Australia's Tobacco Plain Packaging Scheme’ (2019) 20 Journal of World Investment \& Trade 146, 183-4.

${ }^{45}$ See, eg, Henning Grosse Ruse-Khan, ‘The Principle of Integration in WTO/TRIPS Jurisprudence' in Marie CordonierSegger and Judge C G Weeramantry (eds), Sustainable Development Principles in the Decisions of International Courts and Tribunals: 1992-2012 (Routledge, 2017) 398.
} 
This article was published in: (2020) 37(1) Australian Yearbook of International Law, 65-75

https://brill.com/view/journals/auso/37/1/article-p63_5.xml

articles 7 and 8 are therefore significant well beyond tobacco control and the regulation of other unhealthy commodities.

\section{Conclusion}

Overall, the tobacco control cases make clear that non-discriminatory measures regulating the use of trademarks on public health grounds do not violate international intellectual property law, provided they do not affect legal rights regarding registration or exclusion of third parties. The cases also make it clear that adjudicators should appropriately weight public health when dealing with measures that engage intellectual property protections, and that property rights are not absolute and should be interpreted in a way that adequately balances the interests they protect with other public interests. While many of these findings will be specific to the regulation of unhealthy commodities, they also resolve some broader questions about the scope and interpretation of intellectual property rights in international agreements. They are thus landmark contributions to the jurisprudence on intellectual property, public health, and states' ability to regulate for public welfare in international law. 


\section{University Library}

\section{- M M N E R VA A gateway to Melbourne's research publications}

Minerva Access is the Institutional Repository of The University of Melbourne

Author/s:

Liberman, J;Zhou, S

Title:

Public Health, Intellectual Property, and the Trade and Investment Law Challenges to Australia and Uruguay's Tobacco Packaging Laws

Date:

2020

\section{Citation:}

Liberman, J. \& Zhou, S. (2020). Public Health, Intellectual Property, and the Trade and Investment Law Challenges to Australia and Uruguay's Tobacco Packaging Laws. Australian Year Book of International Law, 37 (1), pp.65-75

Persistent Link:

http://hdl.handle.net/11343/245497 